\title{
Assessment of the Effects of Oxidative Stress on Some Reproductive Hormones in Male Hypertensive Subjects at NAUTH, Nnewi
}

Emmanuel Ikechukwu Onwubuya ${ }^{1}$, Nkiruka Rose Ukibe ${ }^{2^{\star}}$, Ofia Anya Kalu ${ }^{1}$, Bonaventure Sunday Agbo ${ }^{2}$, Solomon Nwabueze Ukibe ${ }^{3}$, Ifeoma Nwamaka Monago 4 and Obiageli Fidelia Emelumadu ${ }^{5}$

${ }^{1}$ Department of Internal Medicine, Faculty of Medicine, College of Health Sciences, Nnamdi Azikiwe University, Nnewi Campus, Anambra State, Nigeria ${ }^{2}$ Deparment of Medical Laboratory Science, College of Health Sciences, Nnamdi Azikiwe University, Nnewi Campus, Anambra State, Nigeria

${ }^{3}$ Department of Prosthesis and Orthotics, Federal University of Technology, Owerri, Imo State, Nigeria

${ }^{4}$ Department of Medicine, Federal Medical Center Oko, Anambra state, Nigeria

${ }^{5}$ Department of Community Medicine, Faculty of Medicine, College of Health Sciences, Nnamdi Azikiwe University, Nnewi Campus, Anambra State, Nigeria

\begin{abstract}
Background: This is a prospective case control study, aimed at assessing the effect of oxidative stress using Malondialdehyde (MDA) Superoxide Dismutase (SOD) and Total antioxidant capacity (TAC) on some reproductive hormones Follicle stimulating hormone (FSH), Luteinizing hormone (LH) and Testosterone (TT) in male hypertensive subjects at NAUTH Nnewi, Anambra State, Nigeria.

Methods: 90 newly diagnosed adult male hypertensive and sixty normotensive control subjects aged between 30-65 (49.98 \pm 9.90$)$ years were randomly recruited for the study. Blood sample were collected from all the participants, separated and stored frozen at $-20^{\circ} \mathrm{C}$ until assayed for male sex hormones using standard ELISA methods and oxidative stress markers (MDA, SOD and TAC) using Spectrophotometric method. Blood pressures were measured using accosson sphygmomanometer and stethoscope, and high blood pressure was considered when systolic blood pressure (SBP) is greater than $140 \mathrm{mmHg}$ and diastolic blood pressure (DBP) greater than 90 $\mathrm{mmHg}$ persistently for three days. A well-structured questionnaire was administered to ascertain the bio-data and anthropometric index of all the participants.
\end{abstract}

Results: SBP and DBP were significantly higher in hypertensive male subjects $157.10 \pm 15.40,99.40 \pm 8.94)$ compared to controls $(114.50 \pm 8.3,76.60 \pm 5.90)(p=0.000$ respectively). FSH and LH $(11.94 \pm 4.14,8.46 \pm 2.54)$ were significantly higher while TT $(3.19 \pm 1.63)$ was significantly lower in hypertensive subjects compared to controls $(7.16 \pm 3.40,3.31 \pm 1.74)(7.32 \pm 2.54)(p=0.000$ respectively). More so, the mean levels of MDA and SOD in hypertensive subjects $(1.43 \pm 0.45,15.36 \pm 6.15)$ were significantly higher compared to control $(0.63 \pm 0.29,5.28$ $\pm 2.70)(p=0.000)$ while TAC in hypertensive subjects $(18.19 \pm 5.46)$ was significantly lower compared to control subjects $(36.93 \pm 7.55)(p=0.000)$. Significant positive correlation was observed between SBP, DBP and FSH, LH, SOD, MDA while significant negative correlation existed between SBP, DBP and TT, TAC. TT and LH were significantly positively correlated with TAC and MDA.

Conclusion: Hypertensive male subjects showed significantly higher levels of FSH and LH with lower testosterone levels which suggest hypogonadism and significantly higher MDA and SOD with lower levels of TAC indicating some degree of oxidative stress with suppressed body's antioxidant defense. The positive and negative correlation observed in blood pressure, male sex hormones and oxidative stress markers also showed that oxidative stress may contribute significantly to the hypogonadism observed which may affect the reproductive potentials in these subjects.

Keywords: Hypertension; Spectrophotometricmethod;Pathophysiology; Hypogonadism

\section{Introduction}

Hypertension (HTN) also known as high blood pressure (HBP) is a type of metabolic disorder in which blood pressure in the arteries is persistently elevated [1]. Blood pressure is the force blood pushes against the walls of arteries as it flows through them and it usually does not cause symptoms [2]. This is expressed using two measurements, the systolic and diastolic pressures, meaning the maximum and minimum pressures, respectively [2]. The normal blood pressure at rest is established within the range of 100-140 millimeters mercury ( $\mathrm{mmHg}$ ) systolic and 60-90 $\mathrm{mmHg}$ diastolic [3]. It is indicated that high blood pressure is present if the resting blood pressure is persistently at or above 140/90 $\mathrm{mmHg}$ for most adults [4]. Hypertension has been established as a major risk factor for cardiovascular disease as well as erectile dysfunction $[5,6]$.

Chobanian et al. [7] have grouped high blood pressure into different stages as Normal stage $=(90 / 60-119 / 79)$, High normal, $($ pre-hypertensive $)$ stage $=(120 / 80-139 / 89)$, Stage 1 hypertension $=(140 / 90-159 / 99)$, Stage 2 hypertension $=(160 / 100-179 / 109)$, Stage 3 hypertension $($ Emergency $)=$ $(>180 />110)$, Isolated systolic hypertension $=(>140 /<90)$. However, Ehret et al. [8] grouped hypertension into two types; primary and secondary hypertension. Primary hypertension (essential hypertension) results from a complex interaction of genes and environmental factors. The authors indicated that some genetic variants have minimal effects on

*Corresponding author: Nkiruka Rose Ukibe, Deparment of Medical Laboratory Science, College of Health Sciences, Nnamdi Azikiwe University, Nnewi Campus, Anambra State, Nigeria, Tel: +2348062915510; E-mail: nr.ukibe@unizik.edu.ng; ezinne4real2007@yahoo.com

Received February 28, 2018; Accepted April 19, 2018; Published April 27, 2018

Citation: Onwubuya El, Ukibe NR, Kalu OA, Agbo BS, Ukibe SN, et al. (2018) Assessment of the Effects of Oxidative Stress on Some Reproductive Hormones in Male Hypertensive Subjects at NAUTH, Nnewi. J Bioanal Biomed 10: 64-69. doi:10.4172/1948-593X.1000207

Copyright: @ 2018 Onwubuya El, et al. This is an open-access article distributed under the terms of the Creative Commons Attribution License, which permits unrestricted use, distribution, and reproduction in any medium, provided the original author and source are credited. 
blood pressure while some rare genetic variants have tremendous effects on blood pressure. The environmental factors which influence blood pressure include: high salt intake, this raises the blood pressure in salt sensitive individuals; lack of exercise, obesity, depression and stress [9].

Stress on the other hand, is a body response to any kind of demand or threat including protection of the body when working properly. If stress is prolonged, it becomes dangerous and can lead to adjustments in homeostasis including pathological effects on metabolism, vascular function, tissue repair, immune function, nervous and endocrine system function thereby releasing a flood of stress hormones [10].

The imbalance between the production of reactive oxygen species (ROS) and anti-oxidant defense is termed oxidative stress [11]. The natural byproduct of the normal metabolism of oxygen is known as ROS; it includes peroxides, superoxide, hydroxyl radical and singlet oxygen. ROS can be produced from pollutants, tobacco, smoke, drugs, xenobiotics, eating unhealthy diet or radiation and during stress; ROS levels can be elevated resulting in oxidative stress [12] but the antioxidants are needed in the body to counteract the effects of the free radicals thereby reducing oxidative stress.

Several reports have established that ROS can influence the vascular, renal, cardiac function and structure by modulating cell growth, contracting and dilatation of cell, and inflammatory responses through redox-dependent signaling pathways [13-15]. Evidence has shown that reactive oxygen species plays an important role in the pathophysiology of hypertension. The vasculature is a rich source of Nicotinamide adenine di-phosphate (NADPH) which produces most of the reactive oxygen species and plays an important role in renal dysfunction and vascular damage leading to erectile dysfunction [16]. The authors indicated that increased oxidative stress is grossly implicated in the endothelial damage and pathogenesis of hypertension with reduced bioavailability of antioxidants.

The important male reproductive hormones are Follicle Stimulating Hormone (FSH), Luteinizing Hormone (LH) and Testosterone (TT). FSH stimulates sperm production while (LH) known as interstitial cell stimulating hormone (ICSH) stimulates testosterone production that is needed for sperm production. Testosterone (TT) on the other hand, stimulates secondary sex characteristics and sex drives [17]. Stress has been implicated in male infertility; it also affects the testicular function [18]. Reports have shown that lower circulating testosterone and androstenedione levels are implicated in hypertension [19-21]. This may reflect increased stress. It has been indicated that testosterone level lowers in response to stress induced by myocardial infarction, surgery, head trauma, burns, hypoxia, sleep deprivation and psychological stressors [22]. On the other hand, testosterone has been reported to have pro-hypertensive effects by enhancing the activity of tyrosine hydroxylase, which is the rate limiting enzyme in norepinephrine synthesis. The overall increase in norepinephrine levels can lead to the development of hypertension in male animals [23]. Testosterone also up-regulates the release of the potent vasoconstrictor neuropeptide Y [24]. This shows that testosterone can activate the mechanisms that cause both vasoconstriction and vasorelaxation and the balance can determine its net effect on blood pressure, hence the health implication of this in adult hypertensive men.

\section{Materials and Methods}

\section{Subjects}

A total of 150 male individuals were randomly recruited for this study at Nnamdi Azikiwe University Teaching Hospital Nnewi, and were divided into 2 groups, which includes 90 newly diagnosed hypertensive male subjects and 60 non-hypertensive male subjects (control). The subjects were all adult males between the ages of 30-65 $(49.98 \pm 9.90)$ years.

\section{Study design}

This was a prospective case control study designed to assess the impact of oxidative stress on male sex hormone (FSH, LH and TT) of men diagnosed with hypertension at Nnamdi Azikiwe University Teaching Hospital Nnewi (NAUTH) to ascertain their fertility state. The subjects were randomly recruited after obtaining their consent. Anthropometric measurements including Body mass index (BMI) was calculated as weight, divided by height squared $\left(\mathrm{kg} / \mathrm{m}^{2}\right)$. While Blood pressure was taken on the left arm after 5 min relaxation, in a sitting position, using a standard mercury sphygmomanometer with appropriate cuff size. Systolic (SBP) and diastolic (DBP) blood pressures corresponded to Korotkoff sounds 1 and $\mathrm{V}$ respectively. The average of three readings, taken at first, was used for further analysis. A well-structured questionnaire was used to ascertain their knowledge about hypertension and fertility status. $10 \mathrm{ml}$ of blood sample was aseptically collected between 8-10am and dispensed into a well labeled plain tube and allowed to clot, retract and centrifuged at 3,000rpm for 5 $\mathrm{min}$. The serum was separated into well labeled plain bottles and stored frozen at $-20^{\circ} \mathrm{C}$ until assayed for male sex hormones and oxidative stress parameters.

\section{Exclusion and inclusion criteria}

Those taken anti-hypertensive drugs, fertility drugs, anti-malaria drugs and antioxidant supplementations were excluded from the study. Diabetic patients were equally excluded. Newly diagnosed hypertensive men, age between 30-65 (49.98 \pm 9.90$)$ years who were not yet on any antihypertensive drugs and normotensive men of the same age who serves as control were included in the study.

\section{Methods}

Determination of male sex hormones (Testosterone, Luteinizing hormone and Follicle stimulating hormone) were done according to the methods of Dorfman and Shipley [25], Koasa [26] and Odell et al. [27] respectively, using enzyme-linked immunosorbent assay (ELISA).

\section{Determination of Superoxide Dismutase (SOD) Activity}

This was done using Misra and Fridovich [28] method as described by Akinduko et al. [29] with little modifications.

\section{Principle}

The ability of superoxide dismutase to inhibit the auto oxidation of adrenaline at $\mathrm{pH} 10.2$ makes this reaction a basis for the SOD assay. Superoxide anion $\left(\mathrm{O}^{2-}\right)$ generated by the xanthine oxidase reaction is known to cause the oxidation of adrenaline to adrenochrome. The yield of adrenochrome produced per superoxide anion introduced increased with increasing $\mathrm{pH}$ and also with increasing concentration of adrenaline. These led to the proposal that auto oxidation of adrenaline proceeds by at least two distinct pathways, one of which is a free radical chain reaction involving superoxide radical and hence could be inhibited by SOD. In the Procedure,

Eighty micro liters of sample/blank was added to $1000 \mu \mathrm{l}$ of carbonate buffer ( $\mathrm{pH} \mathrm{10.2)}$, mixed and incubated at $37^{\circ} \mathrm{C}$ for $5 \mathrm{~min}$ and then $600 \mu$ of freshly prepared epinephrine was added and read after 
Citation: Onwubuya El, Ukibe NR, Kalu OA, Agbo BS, Ukibe SN, et al. (2018) Assessment of the Effects of Oxidative Stress on Some Reproductive Hormones in Male Hypertensive Subjects at NAUTH, Nnewi. J Bioanal Biomed 10: 64-69. doi:10.4172/1948-593X.1000207

$30 \mathrm{~s}$, at $30 \mathrm{~s}$ intervals for $150 \mathrm{~s}$ at $480 \mathrm{~nm}$. The serum SOD activity is calculated from the blank and expressed as U/L.

\section{Determination of Malondialdehyde (MDA)}

MDA concentration was estimated as reactive substances by a thiobarbituric acid assay method described by Buege and Aust [30].

Principle: This method quantifies lipid hydro-peroxides by measuring aldehyde break down product of lipid- peroxidation. Basic principle of the method is the reaction of one molecule of malondialdehyde and two molecule of thiobarbituric acid to form a red MDA- TBA complex, which can be measured at $535 \mathrm{~nm}$. Procedure, to $0.4 \mathrm{ml}$ of serum, $0.8 \mathrm{ml}$ TCA-TBA-HCL reagent was added. Mixed well and kept in boiling water bath for $10 \mathrm{~min}$. After cooling $1.0 \mathrm{ml}$ freshly prepared $1 \mathrm{~N} \mathrm{NaOH}$ solution was added so as to eliminate centrifugation. The absorbance of pink colour formed was measured by spectrophotometer against blank at $535 \mathrm{~nm}$. The concentration of MDA was determined using molar extinction coefficient of $1.56 \times 10^{5}$ moles per litre and the results expressed as $\mathrm{nmol} / \mathrm{ml}$.

\section{Estimation of Total Antioxidant Capacity (TAC)}

Total antioxidant statue was estimated by Ferric Reducing Ability of Plasma (FRAP) method by Benzie and Strain, [31].

Principle and procedure: At low $\mathrm{pH}$, antioxidant power causes the reduction of ferric tripyridyl triazine (Fe III TPTZ) complex to ferrous form (which has an intense blue colour) that can be monitored by measuring the change in absorption at $593 \mathrm{~nm}$. Ferric Reducing Ability of Plasma (FRAP) values are obtained by comparing the absorbance change at $593 \mathrm{~nm}$ in mixture (test), with those containing ferrous ion in known concentration (standard). In the procedure, nine hundred microliter $(900 \mu \mathrm{l})$ of working reagent which is a mixture of Acetate buffer, Ferric chloride, and Tripyridyltriazine in the ratio of 10:1:1 respectively was added to $30 \mu \mathrm{l}$ of sample/standard/blank and incubated at $37^{\circ} \mathrm{C}$ for $10 \mathrm{~min}$ and then read at $593 \mathrm{~nm}$. TAS was calculated and expressed in Umol/L.

\section{Anthropometric index}

The assessment of BMI, height, and weight measurements were taken using standard protocols given by Weiner and Lourie [32].

\section{Statistical analysis}

Statistical analyses of the data collected were carried out using SPSS 21.0. Beside descriptive statistics, $\mathrm{t}$-test was done. Correlation analyses were determined by Pearson moment correlation. The results were deemed significant when $\mathrm{p}<0.05$.

\section{Results}

Levels of anthropometric index (age (years), BMI $\left(\mathrm{kg} / \mathrm{m}^{2}\right)$, SBP ( $\mathrm{mmHg})$, DBP $(\mathrm{mmHg}))$ in hypertensive and control subjects

In the present study the mean levels of age and BMI in hypertensive subjects $(49.27 \pm 9.60,25.18 \pm 6.50)$ were not significantly different when compared to control subjects $(48.70 \pm 10.30,26.70 \pm 5.00)$ ( $p>0.05)$. On the other hand, the mean values of SBP and DBP were significantly higher in hypertensive subjects $(157.10 \pm 15.40,99.40 \pm$ 8.94) when compared to control subjects $(114.50 \pm 8.30,76.60 \pm 5.90)$ $(\mathrm{p}=0.000$ respectively) (Table 1$)$.
Levels of FSH $(\mathrm{mIU} / \mathrm{ml})$, $\mathrm{LH}(\mathrm{mIU} / \mathrm{ml})$ and TT $(\mathrm{ng} / \mathrm{ml})$ in hypertensive and control subjects

In the present study the mean values of FSH and LH were significantly higher in hypertensive subjects (11.94 $\pm 4.14,8.46 \pm$ 2.54) when compared to control subjects $(7.16 \pm 3.40,3.31 \pm 1.74)$ ( $\mathrm{p}=0.000$ respectively). On the contrary, the mean value of the TT in hypertensive subjects $(3.19 \pm 2.63)$ was significantly lower compared to the corresponding control subjects $(7.32 \pm 1.54)(\mathrm{p}=0.000)$ Table 2 .

Levels of TAC (Umol/L), MDA (nmol/ml) and SOD (U/L) in hypertensive and control subjects

The results show mean TAC in the hypertensive subjects (18.19 $\pm 5.46)$ was significantly lower compared to control subjects (36.93 \pm $7.55)(\mathrm{p}=0.000)$. On the other hand, the mean MDA and SOD levels in hypertensive subjects $(1.43 \pm 0.45,15.36 \pm 6.15)$ were significantly higher compared to control subjects $(0.63 \pm 029,5.28 \pm 2.70)(\mathrm{p}=0.000$ respectively) (Table 3 ).

Relationship between hypertension (SBP \& DBP), male sex hormone (FSH, LH \& TT) and oxidative stress markers (TAC, MDA \& SOD)

There was significant positive correlation between SBP, DBP and sex hormones FSH, LH. Similar correlation existed between SBP, DBP and oxidative stress markers SOD and MDA while significant negative correlation were observed between SBP, DBP and TT, TAC.

Similarly, there was significant positive relationship between (TT vs. TAC and LH vs. MDA) $(\mathrm{r}=0.287,0.211)(\mathrm{p}=0.006,0.046)$. In contrast significant negative relationship existed between (LH $v s$. TAC and TT vs. MDA) $(\mathrm{r}=-0.247,-0.237)(\mathrm{p}=0.019,0.025)($ Table 4$)$.

\section{Discussion}

In the present study, the significantly higher Body mass index (BMI) observed in hypertensive subjects showed that they were overweight. This may be due to common risk factors for hypertension and obesity which can result to cardiovascular disease. Obesity has been grossly implicated in cardiovascular diseases [33]. Reports have shown that oxidative stress increases with increasing BMI [34]. The author

\begin{tabular}{|c|c|c|c|c|}
\hline Parameter & $\begin{array}{c}\text { Hypertensive } \\
\text { subjects (n=90) }\end{array}$ & $\begin{array}{c}\text { Control } \\
\text { Subjects(n=60) }\end{array}$ & t-value & P-value \\
\hline Age & $49.27 \pm 9.60$ & $48.70 \pm 10.30$ & 0.220 & 0.827 \\
\hline BMI & $25.18 \pm 6.50$ & $26.70 \pm 5.00$ & -1.006 & 0.319 \\
\hline SBP & $157.10 \pm 15.40$ & $114.50 \pm 8.30$ & 13.312 & 0.000 \\
\hline DBP & $99.40 \pm 8.94$ & $76.60 \pm 5.90$ & 11.610 & 0.000 \\
\hline
\end{tabular}

Table 1: Mean $\pm(\mathrm{SD})$ age, BMI, SBP and DBP in hypertensive and control subjects.

\begin{tabular}{|c|c|c|c|c|}
\hline Parameter & $\begin{array}{c}\text { Hypertensive } \\
\text { subjects (n=90) }\end{array}$ & $\begin{array}{c}\text { Control } \\
\text { Subjects(n=60) }\end{array}$ & t-value & P-value \\
\hline FSH & $11.94 \pm 4.14$ & $7.16 \pm 3.40$ & 7.382 & 0.000 \\
\hline LH & $8.46 \pm 2.54$ & $3.31 \pm 1.74$ & 13.669 & 0.000 \\
\hline TT & $3.19 \pm 2.63$ & $7.32 \pm 1.54$ & -10.970 & 0.000 \\
\hline
\end{tabular}

Table 2: Mean $\pm(\mathrm{SD}) \mathrm{FSH}, \mathrm{LH}$, and TT in hypertensive and control subjects.

\begin{tabular}{|c|c|c|c|c|}
\hline Parameter & $\begin{array}{c}\text { Hypertensive } \\
\text { subjects } \mathbf{( n = 9 0 )}\end{array}$ & $\begin{array}{c}\text { Control } \\
\text { Subjects(n=60) }\end{array}$ & t-value & P-value \\
\hline TAC & $18.19 \pm 5.46$ & $36.93 \pm 7.55$ & -17.638 & 0.000 \\
\hline MDA & $1.43 \pm 0.45$ & $0.63 \pm 0.29$ & 12.157 & 0.000 \\
\hline SOD & $15.36 \pm 6.15$ & $5.28 \pm 2.70$ & 11.932 & 0.000 \\
\hline
\end{tabular}

Table 3: Mean $\pm(S D)$ TAC, MDA and SOD in hypertensive and control subjects. 


\begin{tabular}{|c|c|c|}
\hline Parameters & R-value & P-value \\
\hline SBP vs. FSH & $0.596^{* *}$ & 0.000 \\
\hline SBP vs. LH & $0.676^{* *}$ & 0.000 \\
\hline SBP vs. TT & $-0.698^{* *}$ & 0.000 \\
\hline SBP vs. TAC & $-0.705^{* *}$ & 0.000 \\
\hline SBP vs. SOD & $0.665^{* *}$ & 0.000 \\
\hline SBP vs. MDA & $0.603^{* *}$ & 0.000 \\
\hline DBP vs. FSH & $0.569^{* *}$ & 0.000 \\
\hline DBP vs. LH & $0.682^{* *}$ & 0.000 \\
\hline DBP vs. TT & $-0.646^{* *}$ & 0.000 \\
\hline DBP vs. TAC & $-0.613^{* *}$ & 0.000 \\
\hline DBP vs. SOD & $0.601^{* *}$ & 0.000 \\
\hline DBP vs. MDA & $0.5266^{* *}$ & 0.000 \\
\hline LH vs. TAC & $-0.247^{* *}$ & 0.019 \\
\hline LH vs. MDA & $0.211^{* *}$ & 0.046 \\
\hline TT vs. TAC & $0.287^{* *}$ & 0.006 \\
\hline TT vs. MDA & $-0.237^{* *}$ & 0.025 \\
\hline
\end{tabular}

Table 4: Relationship between hypertension, male sex hormones and oxidative stress markers.

attributed this to be due to an increase in seminal macrophage activation. This can have a negative effect on male reproductive hormones due to increasing ROS production [35]. BMI has been found to be associated with altered sperm parameters in numerous reports [36-38]. Increased and prolonged oxidative stress causes testicular damage which impedes spermatogenesis resulting in decreased sperm count $[39,40]$. It has also been reported that about $25-80 \%$ of males with infertility record high levels of ROS [41,42]. Several studies have associated semen quality with increased BMI which have in overall, affected male reproductive life [36-38]. The authors attributed the altered spermatogenesis and reduced total sperm count and concentration to absolute generation of reactive oxygen species (ROS), dysregulation of the hypothalamicpituitary-gonadal (HPG) axis, and/or physical manifestations such as hypertension. When production of reactive oxygen species (ROS) is increased and/or their metabolism by anti-oxidant enzymes is impaired, this results to oxidative stress. Oxidative stress is believed to play an important role in both the initiation and progression of a variety of vascular diseases, including hypertension and atherosclerosis [43].

The mean systolic and diastolic blood pressures were significantly higher among hypertensive subjects than in controls. The results strongly indicate that the subjects used were hypertensive [44]. Mungreiphy et al. [45] reported that the mean SBP and DBP were significantly higher among hypertensive individuals than the normotensive individuals with elevated BMI. The study done by Suman et al. [46] also showed that the mean value of weight, height, pulse rate, SBP and DBP were significantly higher in hypertensive individuals compared to their control. However, chronic oxidative stress occurs when obesity is associated with hypertension [47-49]. Hypertension is a common risk factor for cardiovascular disease including myocardiac infarction, stroke, chronic kidney diseases and metabolic abnormalities [49-51]. These can lead to reduction in individual life span if appropriate health interventions are not in place $[49,50]$. It has been established that oxidative stress plays a major role in the pathogenesis of hypertension $[52,53]$. Human hypertension is associated with a decrease in NO bioavailability and an increase in oxidative stress as well as increased deposition of fats in the arterial walls $[54,55]$. Caloric restriction in hypertensive men would lead to marked reduction in ROS generation and other indices of oxidative stress [56] thereby improving wellbeing and reproductive potentials of the affected individuals.
The findings showed that the mean FSH and LH levels were significantly higher while Testosterone levels were significantly lower in hypertensive subjects compared to control subjects. The increase may be as result of loss of negative feedback control action of testosterone to hypothalamic-pituitary system. Increase in FSH and LH may also be as a result of increased level of activin, which is known to increase FSH binding and its biosynthesis and oppose the effects of inhibin on FSH. Activin also participates in androgen synthesis by enhancing $\mathrm{LH}$ action in the testes [57]. This is in line with the work done by Hayes et al. [58]. He observed that a decrease in testosterone levels increases the secretion of LH and FSH via negative feedback to hypothalamus and pituitary gland. The decrease seen in testosterone also agreed with the works of Kotitschke et al. [59] and Hu [60]. They deduced that stress causes testosterone depletion; this is because the major target cells in stress condition are sertolic cells which aid testosterone production and are involved in spermatogenesis [59]. HU, [60] observed that glucocorticoid are synthesized in excess during oxidative stress and it reduces the testicular response to $\mathrm{LH}$ and concentration of LH receptor which lead to reduced testosterone secretion. On the contrary, Whirledge and Cidlowski [61] observed a significantly lower level of FSH and LH in hypertensive individuals and attributed it to down regulation of GnRH in the Hypothalamic-Pituitary-Gonadal system which leads to impairments of pulsatile release of LH and FSH from pituitary gland. The significant increase in Follicle stimulating hormone in the present study is consistent with other findings [57]. This may be due to increase in activin level which is known to elevate FSH binding and biosynthesis, thereby inhibiting the effect of inhibin on FSH particularly during oxidative stress [57].

The mean value of TAS was significantly lower in hypertensive subjects compared to control subjects. This may be attributed to decrease in body antioxidant defense due to increase in free radicals. This finding is in consistent with other reports $[62,63]$. Marques et al. [64] also demonstrated that increased free radical production in the body can aggravate oxidative damage. The authors attributed this to decrease in antioxidant levels in the body [65]. Pinchuk et al. [66] also observed that TAC decreases with increased oxidative stress in hypertensive individuals. The author also attributed it to excessive free radical that may lead to increased oxidative stress damage. Free radicals are highly reactive and are active participants in different processes. They do not only act as damaging agents, but are very vital in many normal functions of living organisms.

The mean values of MDA and SOD were significantly higher in hypertensive subjects when compared with control subjects. The increased MDA and SOD with decreased TAC in hypertensive subjects could be an indication of oxidative stress. Malondialdehyde is a naturally occurring product of lipid peroxidation. Lipid peroxidation is a well-established mechanism of cellular injury in both plants and animals and is used as an indicator of oxidative stress in cells and tissues $[67,68]$. The work of Lefevre et al. [69] observed that the bulk of MDA in human plasma is bound to protein; this explains the very low levels of MDA in plasma as measured under standard assay conditions. Pedrol et al. [70] revealed increased MDA, uric acid, lipid function profile and decrease SOD, CAT, and TAC in hypertension while Kornelia et al. [71] reported that though MDA increased, SOD and CAT do not decrease in hypertension.

The significant positive correlation between FSH, LH and blood pressure indices with significant negative correlation between testosterone and some parameters is suggestive of hypertension which can grossly affect the reproductive potentials of the affected subjects. 
Citation: Onwubuya El, Ukibe NR, Kalu OA, Agbo BS, Ukibe SN, et al. (2018) Assessment of the Effects of Oxidative Stress on Some Reproductive Hormones in Male Hypertensive Subjects at NAUTH, Nnewi. J Bioanal Biomed 10: 64-69. doi:10.4172/1948-593X.1000207

Similar observation was made between MDA, SOD, TAC and blood pressure parameters showing that hypertension is significantly implicated in oxidative stress damage with reduced antioxidant defenses. Fischer and Swain [72] reported that testosterone alters blood pressure in opposite direction.

The significant negative correlation between LH, TT and MDA, TAC is consistent with work done by Tim, [73]. The author attributed the strong relationship to the production of TT by leydig cells in response to LH. FSH on the other hand, acts on sertolic cells to aid spermatogenesis [58]. However, oxidative stress affects leydig cells thereby leading to low production of TT as a result of low response to LH. Increased oxidative stress results in decreased total antioxidant status of the body. The increase in glucocorticoid as a result of stress had led to increase in lipid peroxidation (MDA). The study of $\mathrm{HU}[60]$ showed that increased lipid peroxidation covers $\mathrm{LH}$ receptor to leydig cells and this can elevate LH levels in the blood thereby preventing the production of TT. Furthermore, positive relationships were observed between TT and TAC, LH and MDA. Although sertolic cells are affected by stress which causes low level of testosterone, the FSH loop seems to be less affected by the stress mechanism than LH loop [74]. This may be the reason why FSH had no significant relationship with oxidative stress markers. The positive correlation seen in TT $v$ s. TAC shows that TT is affected by stress and this may lead to decreased TAC in the body. While LH increased as result of negative feedback control, there was a proportional increase in MDA. These findings strongly showed that oxidative stress can affect male reproductive hormones.

\section{Conclusion}

There were significantly higher levels of FSH, LH with lower TT in hypertensive subjects compared to non-hypertensives which suggests hypogonadism. This may lead to impaired reproductive function. The high levels of MDA, SOD with lower level of TAC in hypertensive subjects compared to control subjects may be attributed to lipid peroxidation due to some degree of oxidative stress with suppressed body's antioxidant defense in hypertensive subjects. The significant positive and negative correlation observed in some male sex hormone, oxidative stress markers and hypertensive indices showed a strong relationship between them. The present study therefore, concludes that increase in blood pressure was associated with increased oxidative stress markers, FSH and LH and decreased testosterone in the study population.

\section{Acknowledgement}

We are immensely grateful to all the male Hypertensive subjects attending Nnamdi Azikiwe University Teaching Hospital, Nnewi, Anambra State, Nigeria for given us their informed consent to use their sample for analysis.

\section{Funding}

There is no funding source.

\section{Availability of Data and Materials}

All data and materials are available.

\section{Authors' Contributions}

NRU, EIO and BSA participated in the project design, data analysis and manuscript. SNU, OAK, INM and OFE performed major experiments. All authors read and approved the final manuscript.

\section{Ethics Approval and Consent to Participate}

All authors hereby declare that all experiment and procedure have been examined and approved by the appropriate board of ethics committee of Nnamdi Azikiwe University Teaching Hospital Nnewi, South East Nigeria, and research have therefore been performed in accordance with the standards laid down in the 1964 Declaration of Helsinki.

\section{References}

1. Naish J, Court DS (2014) Medical sciences. ( $\left.2^{\text {nd }} e d n\right), ~ p: 562$.

2. Lackland DT, Weber MA (2015) Global burden of cardiovascular disease and stroke: hypertension at the core. The Canadian J Cardiol 31: 569-571.

3. Giuseppe M, Fagard R, Narkiewicz K, Redon J, Zanchetti A, et al. (2013) $\mathrm{ESH} / \mathrm{ESC}$ Guidelines for the management of arterial hypertension: The Task Force for the management of arterial hypertension of the European Society of Hypertension (ESH) and of the European Society of Cardiology (ESC). Eur Heart J 34: 2159-2219.

4. Poulter NR, Prabhakaran D, Caulfield M (2015) Hypertension. Lancet 386: 801-812.

5. Kostis JB, Jackson G, Rosen R, Barrett-Connor E, Billups K, et al. (2005) Sexual dysfunction and cardiac risk (The Second Princeton Consensus Conference) Am J Cardiol 96: 313-321.

6. Wylie k (2008) Erectile dysfunction. Adv Psychosomal Med 29: 33-45

7. Chobanian AV, Bakris GL, Black HR, Cushman WC, Green LA, et al. (2003) Seventh report of the Joint National Committee on Prevention, Detection, Evaluation, and Treatment of High Blood Pressure. Hypertension 42: 1206-1252.

8. International Consortium for Blood Pressure Genome-Wide Association Studies, Ehret GB, Munroe PB, Rice KM, Bochud M, et al. (2011) Genetic variants in novel pathways influences blood pressure and cardiovascular disease risk. Nature 478: 103-109.

9. Marshall IJ, Wolfe CD, McKevitt C (2012) Lay perspectives on hypertension and drug adherence: systematic review of qualitative research. Br Med J 345: 39-53.

10. McEwen BS (2006) Protective and damaging effects of stress mediators: central role of the brain. Dialogues Clin Neurosci 8: 367-368.

11. Rahman K (2007) Studies on free radicals, antioxidants, and co-factors. Clin Interv Aging 2: 219-236.

12. Devasagayam T, Tilak JC, Boloor K, Sane KS, Ghaskadbi S, et al. (2004) Free Radicals and Antioxidants in Human Health: Current Status and Future Prospects. J Assoc Physic India 52: 796-799.

13. Ebrahimian T, Touyz RM (2008) Thioredoxin in vascular biology: role in hypertension. Antioxid Redox Signal 10: 1127-1136.

14. Gillespie MN, Pastukh V, Ruchko MV (2009) Oxidative DNA modifications in hypoxic signaling. Ann New York Academy of Sci 177: 140-150.

15. Suvorava T, Kojda G (2009) Reactive oxygen species as cardiovascula mediators: lessons from endothelial-specific protein overexpression mouse models. Biochem Biophysis Acta 1787: 802-810.

16. Sinha N, Dabla PK (2015) Oxidative stress and antioxidants in hypertension-a current review. Curr Hypertens Rev 11: 132-142.

17. Davì G1, Falco A (2005) Oxidant stress, inflammation and atherogenesis Lupus 14: 760-764.

18. Vaziri ND (2004) Roles of oxidative stress and antioxidant therapy in chronic kidney disease and hypertension. Curr Opin Nephrol Hypertens 13: 93-99.

19. Phillips GB, Jing TY, Resnik LM, Barbagallo M, Laragh JH, et al. (1993) Sex hormones and hemostatic risk factors for coronary heart disease in men with hypertension. J Hypertens 11: 699-702.

20. Jaffe A, Chen Y, Kisch ES, Fischel B, Alon M, et al. (1996) Erectile dysfunction in hypertensive subjects. Assessment of potential determinants. Hypertension 28: 859-862.

21. Hughes GS, Mathur RS, Margolius HS (1989) Sex steroid hormones are altered in essential hypertension. J Hypertens 7: 181-187.

22. Kalin MF, Zumhoff B (1990) Sex hormones and coronary artery disease: a review of clinical studies. Steroids 55: 330-352.

23. Kumai T, Tanaka M, Watanabe M, Nakura H, Kobayashi S (1995) Influence of androgens on tyrosine hydroxylase mRNA in adrenal medulla of spontaneously hypertensive rats. Hypertension 26: 208-212.

24. Zukowska-Grojec Z (1995) Neuropeptide Y. A novel sympathetic stress hormone and more. Ann N Y Acad Sci 771: 219-233.

25. Dorfman RI, Shipley RA (1956) Estimation of Androgens. New York Edition John Wiley and Sons publishers, pp: 91-98. 
26. Kosasa TS (1981) Measurement of human chorionic gonadotropin. J Reprod Med 26: 201-206.

27. Odell WD, Parlow AF (1981) Measurement of Human Follicle stimulating Hormones. J Clin Invest. 47: 25-51.

28. Misra HP, Fridovich I (1972) The role of superoxide anion in the autoxidation of epinephrine and a simple assay for superoxide dismutase. J Biol Chem 247: 3170-3175.

29. Akinduko DS, Olatosin TM, Uche CZ (2014) Antioxidant capacity of moringaoleifera seed oil against ccl4 induced hepatocellular lipid peroxidation. Eur J Explanatory Biol 4: 514-518.

30. Svingen BA, Buege JA, O'Neal FO, Aust SD (1979) The mechanism of NADPH-dependent lipid peroxidation. The propagation of lipid peroxidation. J Biol Chem 254: 5892-5899.

31. Benzie IF, Strain JJ (1996) The ferric reducing ability of plasma (FRAP) as a measure of "antioxidant power": the FRAP assay. J Analyt Biochem 239: 70-76.

32. Weiner JS, Lourie JA (1981) Practical Human Biology. Academic Press London, UK, pp: 122-128.

33. Pelkonen R, Nikkila EA, Koskinen S (1977) Association of serum lipids and obesity with cardiovascular mortality. Bri Med J 2: 1185-1187.

34. Wonisch W, Falk A, Sundl I, Winklhofer-Roob BM, Lindschinger M (2011) Oxidative stress increases continuously with BMI and age with unfavourable profiles in males. Aging Male 15: 159-65.

35. Tunc O, Bakos HW, Tremellen K (2011) Impact of body mass index on seminal oxidative stress. Andrologia 43: 121-128.

36. Koloszár S, Fejes I, Závaczki Z, Daru J, Szöllosi J, et al. (2005) Effect of body weight on sperm concentration in normozoospermic males. Arch Androl 51 299-304.

37. Kort HI, Massey JB, Elsner CW, Mitchell-Leef D, Shapiro DB, et al. (2006) Impact of body mass index values on sperm quantity and quality. J Androl 27 450-452.

38. Magnusdottir EV, Thorsteinsson $T$, Thorsteinsdottir $S$, Heimisdottir $M$ Olafsdottir K (2015) Persistent organochlorines, sedentary occupation, obesity and human male subfertility. Hum Reprod 20: 208-215.

39. Eskenazi B, Wyrobek AJ, Sloter E, Kidd SA, Moore L, et al. (2003) The association of age and semen quality in healthy men. Hum Reprod 18: 447-454.

40. Dosumu OO, Akinola OB, Akang EN (2012) Alcohol-induced testicular oxidative stress and cholesterol homeostasis in rats-the therapeutic potential of virgin coconut oil. Middle East Fertil Society J 17: 122-128.

41. de Lamirande E, Leduc BE, Iwasaki A, Hassouna M, Gagnon C (1995) Increased reactive oxygen species formation in semen of patients with spinal cord injury. Fertil Steril 64: 637-642.

42. Kefer JC, Agarwal A, Sabanegh E (2009) Role of antioxidants in the treatment of male infertility. Int J Urol 16: 449-457.

43. Miller AA, De Silva TM, Jackman KA, Sobey CG (2007) Effect of gender and sex hormones on vascular oxidative stress. Clin Exp Pharmacol Physiol 34: 1037-1043.

44. Joint National Committee (JNC-7) (2003) New Hypertension Guidelines. Clin Cardiol Alert 54-63.

45. Mungreiphy NK, Kapoor ST, Sinha R (2011) Association between BMI, Blood Pressure, and Age: Study among Tangkhul Naga Tribal N Delhi. Ind J Anthropol 6: 476-482.

46. Suman D, Moniika B, Pankhuri S, Meenal D, Satwanti K (2014) Body mass index relates to blood pressure among adults. North Am J Med Sci 67: 234-245.

47. Nayer A, Ortega LM (2014) Catastrophic antiphospholipid syndrome: A clinical review. J Nephropathol 3: 9-17.

48. Pickering JW, Endre ZH (2013) The definition and detection of acute kidney injury. J Renal Inj Prev 3: 21-25.

49. Nasri H (2012) Comment on: Serum cholesterol and LDL-C in association with level of diastolic blood pressure in type 2 diabetic patients. J Renal Inj Prev 1: 13-14.

50. Behradmanesh S, Nasri P (2012) Serum cholesterol and LDL-C in association with level of diastolic blood pressure in type 2 diabetic patients. J Renal In Prev 1: 23-26.

51. Rafieian-Kopaei M, Nasri H (2013) Ginger and diabetic nephropathy. J Renal Inj Prev 2: 9-10.
52. Montezano AC, Touyz RM (2012) Oxidative stress, Noxs, and hypertension: experimental evidence and clinical controversies. Ann Med 44 Suppl 1: S2-16.

53. Rodrigo R, González J, Paoletto F (2011) The role of oxidative stress in the pathophysiology of hypertension. Hypertens Res 34: 431-440.

54. Rafieian-Kopaei M, Baradaran A, Rafieian M (2013) Plants antioxidants: From laboratory to clinic. J Nephropathol 2: 152-153.

55. Touyz RM (2004) Reactive oxygen species, vascular oxidative stress, and redox signaling in hypertension: What is the clinical significance? Hypertension 44: $248-252$

56. Dandona P, Mohanty P, Ghanim H, Al-jada A, Browne R, et al (2001) The suppressive effect of dietary restriction and weight loss in the obese on the generation of reactive oxygen species by +leukocytes, lipid per-oxidation, and protein carbonylation. J Clin Endocrinol Metab 86: 355-362.

57. Xia Y, Schneyer AL (2009) The biology of activin: recent advances in structure, regulation and function. J Endocrinol 202: 1-12.

58. Hayes FJ, Decruz S, Seminara SB, Boepple PA, Crowley WF Jr (2001) Differential regulation of gonadotropin secretion by testosterone in the human male: absence of a negative feedback effect of testosterone on folliclestimulating hormone secretion. J Clin Endocrinol Metab 86: 53-58.

59. Kotitschke A, Sadie-Van Gijsen H, Avenant C, Fernandes S, Hapgood JP (2005) Genomic and nongenomic cross talk between the gonadotropinreleasing hormone receptor and glucocorticoid receptor signaling pathways. Mol Endocrinol J 23: 1726-1745.

60. Hu GX, Lian QQ, Lin H, Latif SA, Morris DJ, et al. (2008) Rapid mechanisms of glucocorticoid signaling in the Leydig cell. Steroids 73: 1018-1024.

61. Whirledge S, Cidlowski JA (2010) Glucocorticoids, stress, and fertility. Minerva Endocrinol 35: 109-125.

62. Ghiselli A, Serafini M, Natella F, Scaccini C (2000) Total antioxidant capacity as a tool to assess redox status: critical view and experimental data. Free Rad Biolol Med 29: 1106-1114.

63. Kohen R, Nyska A (2002) Oxidation of biological systems: oxidative stress phenomena, antioxidants, redox reactions, and methods for their quantification Toxicol Pathol J 30: 620-650.

64. Marques SS, Magalhães LM, Tóth IV, Segundo MA (2014) Insights on antioxidan assays for biological samples based on the reduction of copper complexes-the importance of analytical conditions. Inter J Mol Sci 15: 11387-1402.

65. Bartsz G (2010) Non-enzymatic antioxidant capacity assays: Limitations of use in biomedicine. Free Radic Biolol Med 44: 711-720.

66. Pinchuk I, Shoval H, Dotan Y, Lichtenberg D (2012) Evaluation of antioxidants scope, limitations and relevance of assays. Chem Physiol Lipids 165: 638-647.

67. Diczfalusy U, Falardeau P, Hammarstrom S (1977) Conversion of prostaglandin endoperoxides to $\mathrm{C} 17$ - hydroxy acids catalyzed by human platelet thromboxane synthase. FEBS Lett 84: 271-274.

68. Plastaras JP, Guengerich FP, Nebert DW, Marnett LJ (2000) Xenobioticmetabolizing cytochromes P450 convert prostaglandin endoperoxide to hydroxyheptadecatrienoic acid and the mutagen, malondialdehyde. J Bio Chem 275: 11784-11790.

69. Lefevre G, Bonneau C, Rahma S, Chanu B, Brault D, et al. (1996) Determination of plasma protein-bound malondialdehyde by derivative spectrophotometry. Eur J Clin Chem Clin Biochem 34: 631-636.

70. Pedro-Botet J, Covas MI, Martín S, Rubiés-Prat J (2000) Decreased endogenous antioxidant enzymatic status in essential hypertension. J Hum Hypertens 14: 343-345.

71. Kornelia KC, Kediora-Kora SN, Towska MU (2004) The markers of oxidative stress and activity of antioxidant system in blood of elderly patient with essentia arterial hypertension. Cell Mol Biol 9: 635-641.

72. Fischer GM, Swain ML (2007) Effect of sex hormones on blood pressure and vascular connective tissue in castrated male rats Am J Physiol 232: 617-621.

73. https://en.wikivet.net/Reproductive_Hormones_Overview_-_Anatomy_\%26_ Physiology

74. Canovatchel WJ (1994) Luteinizing hormone pulsatility in subjects with 5-alphareductase deficiency and decreased dihydrotestosterone production. J Clin Endocrinol Metab 78: 916-921. 